\title{
RESPONSE OF DIFFERENT PLANT SPACING AND NUTRIENTS ON PHYSIOLOGICAL PARAMETERS OF GREENGRAM UNDER
}

\section{IRRIGATED CONDITION}

\author{
M. MOHANA KEERTHI ${ }^{1} \&$ R. BABU ${ }^{2}$ \\ ${ }^{1}$ Research Scholar, Department of Agronomy, Agricultural College and Research Institute, \\ Madurai, Tamil Nadu, India \\ ${ }^{2}$ Professor and Head, Department of Farm Management, Agricultural College and Research Institute
}

Madurai, Tamil Nadu, India

\begin{abstract}
Green gram or mungbean (Vigna radiata L.) is one of the most important food legumes grown and consumed in India. The comprising of various plant spacing, soil and foliar application of fertilizers at varying levels influenced the Leaf area index and Crop growth rate at various stages of crop growth. The plant spacing plays an important role in the dominance and suppression during the process of competition. Soil application of nutrients will give the initial boost for growing seedlings. Use of growth regulators is one of the potent force in improving the growth, flower initiation and yield of agricultural crop especially pulses. The adoption of planting spacing of $30 \times 30 \mathrm{~cm}$, application of recommended dose of fertilizer (RDF), 12.5 tonnes of Farm yard manure (FYM) and $25 \mathrm{~kg}$ Zinc Sulphate $\left(\mathrm{ZnSO}_{4}\right)$ as basal and foliar spraying of $1 \%$ potassium nitrate $\left(\mathrm{KNO}_{3}\right)$ at 50 per cent flowering $\left(\mathrm{T}_{10}\right)$ was recorded highest LAI and CGR at all stages of crop growth.
\end{abstract}

KEYWORDS: Green gram, Plant Spacing, Nutrients, LAI \& CGR

Received: Sep 14, 2017; Accepted: Oct 01, 2017; Published: Oct 16, 2017; Paper Id.: IJASROCT201763

\section{INTRODUCTION}

India is a premier pulse growing country and forms an integral part of, cropping system of the farmers all over the country. The present average per capita consumption of pulses in India was $14 \mathrm{~kg}_{\text {year }}{ }^{-1}$ against the WHO recommendation of $20 \mathrm{~kg} \mathrm{year}^{-1}$ (Indiastat, 2010). Green gram is the third most important pulse crop of India (Chandrasekhar and Ghosh, 2002). Green gram is a rich source of protein (24\%) and also contributes carbohydrates $(60 \%)$, fat $(1.5 \%)$, amino acids, vitamins and minerals, etc. Area under green gram in India is 3.80 million hectares with an annual production of 1.1 million tonnes. In Tamil Nadu, the area under green gram is 0.13 million hectares with an annual production of 458.8 tonnes. The average productivity of green gram, over the globe is $577 \mathrm{~kg} \mathrm{ha}^{-1}$ and in India it is $426 \mathrm{~kg} \mathrm{ha}^{-1}$, which is considered to be low (India stat, 2010). Hence, need to increase the productivity of green gram under irrigated condition. Use of improved crop management packages can invariably increase the productivity.

Plant spacing plays an important role in the dominance and suppression during the process of competition. Ideal plant spacing is precious and important for better and efficient utilization of available plant growth resources in order to increase the physiological growth and get maximum productivity in crops (Rana et al., 2011). The effective fertilizer recommendation was based on the soil nutrient available status and crop requirements and 
foliar application of growth regulators had increased the productivity by the growth rate of the green gram. Foliar application of growth regulators reduced the flower drop and improved the leaf area, pod formation and seed setting percentage (Mir et al., 2010).

\section{MATERIALS AND METHODS}

A field experiment was conducted, during Puratasi pattam from November 2013 to January 2014, at Agricultural College and Research Institute, Killikulam, Tuticorin, Tamil Nadu. The experiment was laid out in randomised block design, with eleven treatments. The treatments were replicated thrice. Greengram CO 6 seeds with a germination percentage of 95 were sown, at the rate of $20 \mathrm{~kg} \mathrm{ha}^{-1}$.

Treatment details

\begin{tabular}{|l|l|l|}
\hline $\mathrm{T}_{1}$ & & $25 \times 25 \mathrm{~cm}$ spacing + STCR based fertilizer application \\
\hline $\mathrm{T}_{2}$ & & $\mathrm{~T}_{1}+\mathrm{ZnSO}_{4}+$ Pulse wonder \\
\hline $\mathrm{T}_{3}$ & & $\mathrm{~T}_{1}+\mathrm{ZnSO}_{4}+$ Pulse wonder + PPFM spray \\
\hline $\mathrm{T}_{4}$ & & $25 \times 25 \mathrm{~cm}$ spacing + RDF + FYM + ZnSO \\
\hline $\mathrm{T}_{5}$ & & $\mathrm{~T}_{4}+1 \% \mathrm{KNO}_{3}$ \\
\hline $\mathrm{T}_{6}$ & & $30 \times 30 \mathrm{~cm}$ spacing + STCR based fertilizer application \\
\hline $\mathrm{T}_{7}$ & & $\mathrm{~T}_{6}+\mathrm{ZnSO}_{4}+$ Pulse wonder \\
\hline $\mathrm{T}_{8}$ & & $\mathrm{~T}_{6}+\mathrm{ZnSO}_{4}+$ Pulse wonder + PPFM spray \\
\hline $\mathrm{T}_{9}$ & $30 \times 30 \mathrm{~cm}$ spacing + RDF + FYM $+\mathrm{ZnSO}_{4}$ \\
\hline $\mathrm{T}_{10}$ & & $\mathrm{~T}_{9}+1 \% \mathrm{KNO}_{3}$ \\
\hline $\mathrm{T}_{11}$ & $30 \times 10 \mathrm{~cm}$ spacing + RDF + FYM + $\mathrm{ZnSO}_{4}$ \\
\hline
\end{tabular}

Note: FYM - 12.5 $\mathrm{t} \mathrm{ha}^{-1}$ as basal; STCR - 13:25:13 $\mathrm{kg} \mathrm{ha}^{-1}$; RDF - 25:50:25:20 NPKS kg ha ${ }^{-1}$;

$\mathrm{ZnSO}_{4}-25 \mathrm{~kg} \mathrm{ha}^{-1}$; Pulse wonder @ $5 \mathrm{~kg} \mathrm{ha}^{-1}$ at 50\% flowering and PPFM - 2\% in one week after flowering

\section{Leaf Area Index (LAI)}

The total number of green leaves, length and breadth of the third leaf from the top of the tagged plants were measured in each plot. The leaf area index was then worked out as suggested by Puttasamy et al. (1976), using the formula as given below.

Leaf area $=\mathrm{L} \times \mathrm{B} \times \mathrm{K}$

Where, L - maximum length of the third leaf from top (cm), B - maximum breadth of the third leaf from top (cm), $\mathrm{K}$ - constant factor $(0.6306)$

$$
\text { LBK } \times \text { No. of leaves plant }{ }^{-1}
$$

$\mathrm{LAI}=$

$$
\text { Land area occupied }\left(\mathrm{cm}^{2}\right)
$$

\section{Crop Growth Rate (CGR)} day $^{-1}$.

The crop growth rate was calculated by using the formula suggested by Watson (1958) and expressed in $\mathrm{kg} \mathrm{ha}^{-1}$

$$
\mathrm{W}_{2}-\mathrm{W}_{1}
$$

$\mathrm{CGR}=$

$$
\left(t_{2}-t_{1}\right)
$$

Where, $\mathrm{W}_{1}$ and $\mathrm{W}_{2}$ were DMP in $\mathrm{kg} \mathrm{ha}^{-1}$ at times $\mathrm{t}_{1}$ and $\mathrm{t}_{2}$ respectively 


\section{RESULT AND DISCUSSIONS}

The plant spacing of $30 \times 30 \mathrm{~cm}$, application of RDF, 12.5 tonnes of FYM and $25 \mathrm{~kg}$ of $\mathrm{ZnSO}_{4}$ as basal and foliar spraying of $1 \% \mathrm{KNO}_{3}$ at 50 per cent flowering $\left(\mathrm{T}_{10}\right)$ recorded the highest LAI $(3.73,5.30$ and 5.61 at 30, 45 DAS and at harvest stage respectively) "Figure 1". The wider spacing gives less competition between inter and intra plants for sun light, water, nutrients and space. This favoured the plant with more leaf area, which harvested more sunlight and produced more photosynthates in the crop. Similar findings were also reported by Mathur et al., (2007) in greengram. The wider plant spacing $30 \times 30 \mathrm{~cm}$ recorded the highest leaf area index, as compared to $25 \times 25 \mathrm{~cm}$ and $30 \times 10 \mathrm{~cm}$ plant spacing. The supply of nutrients which increased the plant growth, number of branches, leaf number, leaf length and breadth and also with more ground coverage (Geetha and Velayutham, 2009) and Hussain et al. (2011).

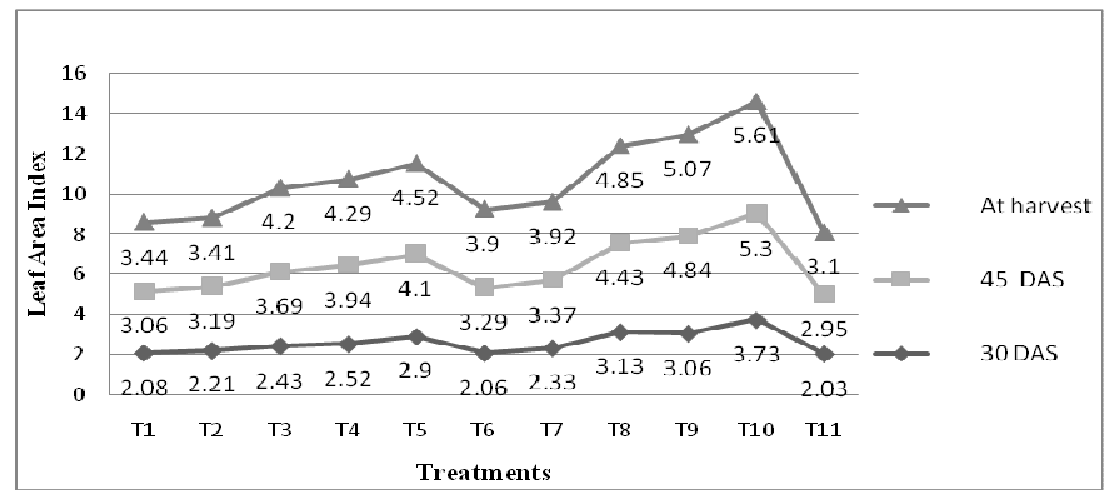

Figure 1: Effect of Plant Spacing and Nutrients on Leaf Area Index (LAI) of Greengram

Crop growth rate increased rapidly from 30 to 45 DAS and tended to decline from 45 DAS to harvest. The treatment comprises of $30 \times 30 \mathrm{~cm}$ plant spacing, application of RDF, 12.5 tonnes of FYM and $25 \mathrm{~kg}$ of $\mathrm{ZnSO}_{4}$ as basal and foliar spraying of $1 \% \mathrm{KNO}_{3}$ at 50 per cent flowering $\left(\mathrm{T}_{10}\right)$ had registered higher CGR value $\left(126.8 \mathrm{~kg} \mathrm{ha}^{-1} \mathrm{day}^{-1}\right)$ at 30 to 45 DAS and $71.0 \mathrm{~kg} \mathrm{ha}^{-1}$ day $^{-1}$ at 45 DAS to harvest "Table 1". This might due to more nutrients uptake in plant with wider planting spacing and favoured accumulation of more dry matter in plants. Similar findings were also reported by Sathyamoorthy et al. (2008) in greengram. The addition of FYM along with RDF and $\mathrm{ZnSO}_{4}$ ensured adequate supply of $\mathrm{N}, \mathrm{P}$ and $\mathrm{Zn}$ as well as balanced supply of nutrients at all stages of crop growth. External application of $\mathrm{N}$ in adequate amount at planting was crucial for initial establishment and further growth of plants. Similarly, P plays an important role in root development and water uptake by plants (Ambhore, 2004).

Table 1: Effect of Plant Spacing and Nutrients on Crop Growth Rate (CGR) of Greengram

\begin{tabular}{|l|c|c|}
\hline \multirow{2}{*}{ Treatments } & \multicolumn{2}{|c|}{ Crop Growth Rate $\left(\mathrm{Kg} \mathrm{Ha}^{-{ }^{-1}} \mathbf{D a y}^{-1}\right)$} \\
\cline { 2 - 3 } & 30 - 45 DAS & 45 DAS - at Harvest \\
\hline $\mathrm{T}_{1}$ & 62.4 & 46.5 \\
\hline $\mathrm{T}_{2}$ & 66.7 & 48.8 \\
\hline $\mathrm{T}_{3}$ & 80.1 & 56.4 \\
\hline $\mathrm{T}_{4}$ & 80.4 & 57.1 \\
\hline $\mathrm{T}_{5}$ & 94.2 & 59.5 \\
\hline $\mathrm{T}_{6}$ & 67.9 & 49.0 \\
\hline $\mathrm{T}_{7}$ & 79.9 & 55.4 \\
\hline $\mathrm{T}_{8}$ & 98.8 & 63.5 \\
\hline $\mathrm{T}_{9}$ & 113.5 & 67.6 \\
\hline $\mathrm{T}_{10}$ & 126.8 & 71.0 \\
\hline $\mathrm{T}_{11}$ & 55.7 & 42.1 \\
\hline
\end{tabular}




\section{CONCLUSIONS}

\begin{tabular}{|l|c|c|}
\hline \multicolumn{3}{|c|}{ Table 1: contd., } \\
\hline SEd & 9.9 & 6.0 \\
\hline CD $(0.05)$ & 20.7 & 12.6 \\
\hline
\end{tabular}

The research evidence showed, adaptation of plant spacing $30 \times 30 \mathrm{~cm}$, application of recommended dose of fertilizer, 12.5 tonnes of Farm yard manure and $25 \mathrm{~kg}$ Zinc Sulphate as basal and foliar spraying of 1\% potassium nitrate, at 50 percent flowering $\left(\mathrm{T}_{10}\right)$, resulted in higher Physiological growth viz., LAI and CGR. These parameters enhanced the yield of greengram, under irrigated condition.

\section{REFERENCES}

1. Ambhore, A. P. (2004). Response of summer greengram (Vigna radiata L.) to biofertilizer and inorganic fertilizer under south Gujarat conditions. M. Sc (Agri.) Thesis, Dept. of Agronomy, Navsari Agricltural University, Navsari, India.

2. Chandrasekhar, C. P and J. Ghosh. (2002). Food economy in disarray. Indian food industry, 21, 10.

3. Geetha, P. and Velayutham, A. (2009). Refinement of nutrient management techniques for growth, yield and nutrient uptake of rice fallow blackgram. Madras agric. J., 96, 163-166.

4. Hussain, Nazir, Mehdi, Mohammed, Habibkant and Rehana. (2011). Response of nitrogen and phosphorus on growth and yield attributes of blackgram (Vigna mungo). Res. J. Agri. Sci., 2, 334-336.

5. Indiastat. (2010). Ministry of Agriculture. Selected state wise area, production and Productivity of greengram, Govt. of India. In: http://www.india stat.com

6. Mathur, N., J. Singh, S. Bohra, A. Bohra and A. Vyas. (2007). Agronomic evaluation of promising genotypes of mungbean under hyper arid conditions of Indian Thar Desert. Intern. J. of Agril. Res., 2, 537-544.

7. Mir, M., N.A. Mobin, M.A. Khan, N.A. Bhat, K.A. Lone, S.M. Bhat, S.A. Razvi, Wani, Nowsheeba Wani, Sabina Akhter, Shazia Rashid, Nasir Hamid Masoodi and W.A. Payne. (2010). Crop responses to interaction between plant growth regulators and nutrients. J. Phyto., 2, 9-19.

8. Puttasamy, S., S. Thimmegowda and K. Krishnamurthy. (1976). Determination of leaf area in pulses. Current Res., 5, 47-48.

9. Rana M.M., S. H. Chowdhury and M. S. Bhuiya. (2011). Effects of plant population and bio-fertilizer on the growth parameters of three summer mungbean (Vigna radiata L.) cultivars. Bangladesh J. Agril. Res., 36, 537-542

10. Sathyamoorthy, K., M. Mohammed Amanullah, K. Vaiyapuri and E. Somasundaram. (2008). Root growth and yield of greengram (Vigna radiata (L.) Wilczek) as influenced by increased plant density and nutrient management. Journal of App. Sci. Res., 4, 917-924.

11. Watson, D.F. (1958). The dependence of net assimilation rate on leaf area index. Ann. Bot., 23, 37-54. 